\title{
BEHAVIOUR OF PS. PYOCYANEA IN DIFFERENT CONCENTRATIONS OF PENICILLIN*
}

\author{
BY
}

\author{
E. G. MILLWOOD AND M. KLEIN
}

London

SINCE the introduction of penicillin the number of Gram-negative infections has increased. "Penicillin as many have discovered seems almost to foster the growth of Ps. pyocyanea" (Lancet, 1944). Since then eye infections, many of them fatal to the eye, have been reported from different countries. In a series of severe case of pyocyanea keratitis (Bignell, 1951), most were due to contaminated penicillin solutions instilled into the eye after superficial injuries. In many cases the penicillin solutions were unpreserved or insufficiently preserved, and in some instances infection had occurred before leaving the manufacturer or the pharmacy (Theodore, 1951).

The object of the present work was to establish whether penicillin solue tions could be protected against contamination by $P$ s. pyocyanea (aeruginosa by the incorporation of a chemical preservative which would be compatible with the solution and not affect its potency. Several antiseptics chosen from a number previously tested against Ps. pyocyanea (Klein, Millwood, and Walther, 1954) were incorporated in penicillin solutions of $10,100,150$, and 50,000 international units $/ \mathrm{ml}$. The 100 - and $150-$ i.u. $/ \mathrm{ml}$. solutions were made up from solution tablets B.P.C. dissolved in sterile, pyrogen-free, distilled water containing the antiseptic; the $10 \mathrm{i} . \mathrm{u} . / \mathrm{ml}$.-solution consisted of a ten-fold dilution of the $100-\mathrm{i} . \mathrm{u} . / \mathrm{ml}$. solution, also made with sterile, pyrogenfree, distilled water. All the solutions, including unpreserved controls, were stored in clear glass screw-capped bottles at room temperature. Samples were taken aseptically at intervals, the potency was assayed by the method of Fielding (1947), and sterility tests were carried out. A portion of the sample was treated with penicillinase and assayed at the same time, as a control.

The reason for including the weaker solutions of penicillin in the series was to see if any adverse effect of the antiseptic on the penicillin would become obvious in a relatively short time. The results (Fig. 1, opposite) show that preserved solutions of the weaker strength penicillin maintained potency longer than the unpreserved solutions. The rapid decline in potency of the unpreserved controls was due in each case to infection by moulds 


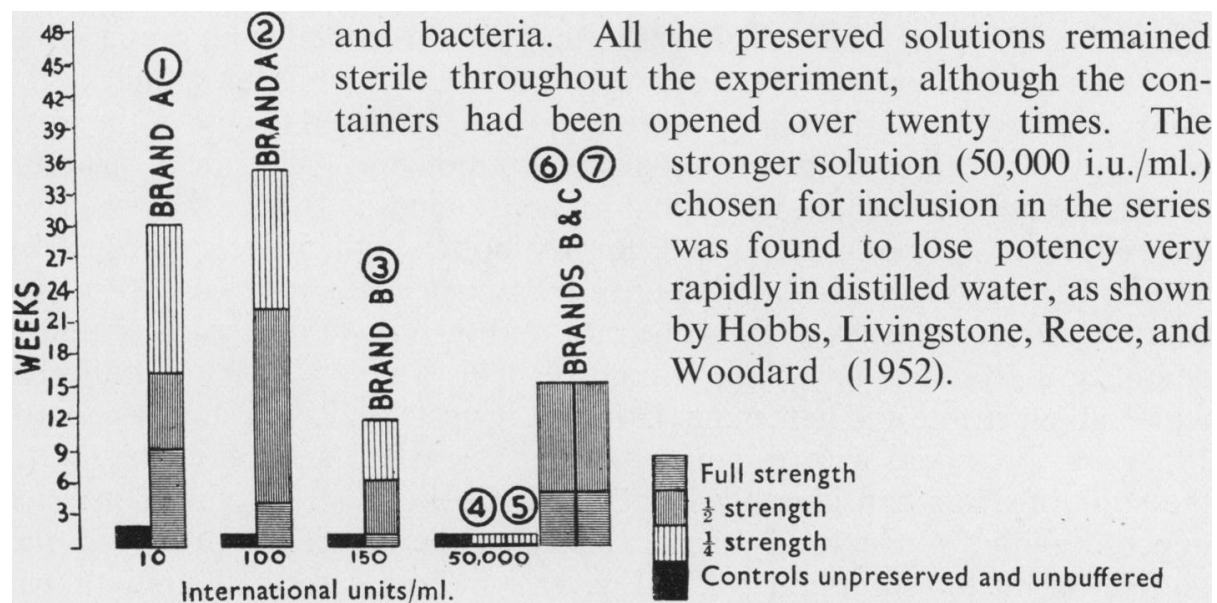

FIG. 1.-Effect of preservatives and buffering agents on potency of penicillin solutions. All solutions were kept at room temperature, and sampled aseptically at weekly intervals.

Col. 1. Average life of solutions preserved with 0.01 per cent. chlorcresol, 0.0002 per cent. thiomersalate, 0.0002 per cent. phenylmercuric nitrate or acetate.

Col. 2. Average life of solutions preserved with 0.1 per cent. chlorcresol, 0.002 per cent. phenylmercuric nitrate, acetate, or thiomersalate.

Col. 3. Solutions preserved as in Col. 2, but different brands.

Col. 4. Average life of solutions (two brands) infected with Ps. pyocyanea.

Col. 5. Average life of solutions (two brands) preserved with 0.002 per cent. thiomersalate or 0.6 per cent. phenylethyl alcohol.

Col. 6. Average life of solutions (two brands) preserved as in Col. 5 and in addition buffered with sodium citrate and hexamine.

Col. 7. Average life of solutions as in Col. 6 infected with Ps. pyocyanea.

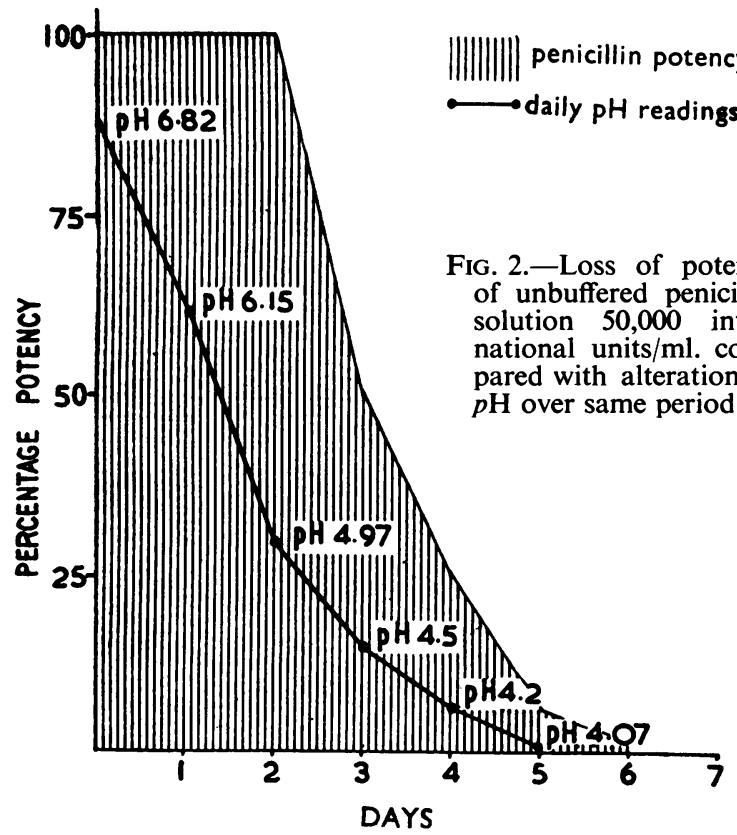

Fig. 2 illustrates the loss of potency compared with the alteration in the $p \mathrm{H}$ due to the conversion of the penicillininto penicilloic acid. It will be noted that the solution had completely deteriorated by the sixth day.

The 50,000-i.u./ml. group of Fig. 1 shows that the period of activity (life) of the control group, unpreserved and unbuffered and noninfected penicillin solutions (marked with black), was the same as that which was 
infected (Col. 4) and that which was unbuffered but contained a preservative $\frac{\vec{J}}{\overline{3}}$ (Col.5). This behaviour of the strong solution was in contrast to that of the weak solutions; the addition of a preservative lengthened the life of the weak solutions significantly, but in the strong solution the inclusion of an antiseptic had no influence on its normal loss of potency. In fact the preserved $\frac{\text { o }}{\circ}$ and unpreserved, both sterile and control bottles, which were infected by $\frac{\bar{\sigma}}{\bar{\sigma}}$ adding $0.2 \mathrm{ml}$. of an 18-hour culture of Ps. pyocyanea to each $100 \mathrm{ml}$. of $\stackrel{\varnothing}{\triangle}$ solution, all lost potency at the same rate, and the loss of potency was almost $\%$ complete in about 6 days (Fig. 1, control; Cols 4 and 5). When buffered, $\vec{\circ}$ with sodium citrate and hexamine (Hobbs, Livingstone, Reece, and Woodard, $\overrightarrow{\vec{H}}$ 1952) and preserved with thiomersalate, or phenylethyl alcohol, the life of $\vec{\sigma}_{\tilde{\sigma}}$ the solutions was considerably lengthened (Col. 6, Fig. 1), and a massive $\frac{\sigma}{0}$. infection with Ps. pyocyanea had no effect on the life of the preserved and $\dot{0}$ buffered penicillin solution (Col. 7, Fig. 1). In both cases half strength was maintained up to 15 weeks.

Another interesting finding was that solutions preserved with thiomersalate kept their potency for about the same length of time as those pre- $\stackrel{\circ}{工}$ served with phenylethyl alcohol. It seems that in the concentration used $\vec{z}$ this heavy metal salt was not deleterious to penicillin. Whether this finding would be applicable to other antibiotics deserves further investigation.

In the course of this work it was noted that the stronger solutions of $\stackrel{\mathbb{E}}{-}$ buffered penicillin, although containing no preservatives, appeared to be $\vec{\theta}$ an unfavourable medium for some strains of Ps. pyocyanea (Table IS on Some bottles containing $10-\mathrm{ml}$. penicillin solution made with penicillio G. and buffered with 0.5 -per cent. sodium citrate dissolved in sterile, pyrogenfree, distilled water were infected with $0.02 \mathrm{ml}$. of an 18-hour culture of Ps. pyocyanea, and $1 \mathrm{ml}$. was subcultured at intervals into 100-ml. Needham's broth containing sufficient penicillinase to inactivate the penicillin. This preliminary experiment has shown that, in a penicillin solution of 25,000 i.u./ml. or stronger, a massive infection of Ps. pyocyanea dies out in 5 to 7 days.

TABLE I

PERSISTENCE OF INFECTION IN PENICILLIN SOLUTION INFECTED WITH 0.02 ML. OF AN 18-HR CULTURE OF Ps. PYOC YANEA (STRAIN P.3)

\begin{tabular}{|c|c|c|c|c|c|c|c|c|}
\hline \multicolumn{2}{|c|}{$\begin{array}{l}\text { Strength of Peni- } \\
\text { cillin Solution } \\
\text { (international } \\
\text { units/ml.) } \ldots\end{array}$} & 100,000 & 50,000 & 25,000 & 15,000 & 5,000 & 2,000 & 1,000 \\
\hline $\begin{array}{l}\text { Time } \\
\text { after } \\
\text { Infection } \\
\text { (days) }\end{array}$ & $\begin{array}{l}1 \\
2 \\
4 \\
5 \\
6 \\
7 \\
8\end{array}$ & $\begin{array}{l}+ \\
+ \\
+ \\
\mathbf{0} \\
\mathbf{0} \\
\mathbf{0} \\
\mathbf{0}\end{array}$ & $\begin{array}{l}+ \\
+ \\
+ \\
+ \\
0 \\
0 \\
0\end{array}$ & $\begin{array}{l}+ \\
+ \\
+ \\
+ \\
+ \\
0 \\
0\end{array}$ & $\begin{array}{l}+ \\
+ \\
+ \\
+ \\
+ \\
+ \\
+\end{array}$ & $\begin{array}{l}+ \\
+ \\
+ \\
+ \\
+ \\
+ \\
+\end{array}$ & $\begin{array}{l}+ \\
+ \\
+ \\
+ \\
+ \\
+ \\
+\end{array}$ & $\begin{array}{l}+ \\
+ \\
+ \\
+ \\
+ \\
+ \\
+\end{array}$ \\
\hline
\end{tabular}

$=$ growth when subcultured 
This experiment was therefore repeated using the three more efficient strengths of penicillin, with the addition of a $15,000-\mathrm{i} . u$. $/ \mathrm{ml}$. solution as a marginal strength. All were buffered with 0.5-per cent. sodium citrate, and were then tested against 27 strains of Ps. pyocyanea isolated from different sources.

Table II shows that the different strains varied in their ability to survive. Tubes containing $10 \mathrm{ml}$. buffered penicillin solution were infected with $0.02 \mathrm{ml}$. of an 18-hr culture of Ps. pyocyanea; 27 strains isolated from various sources were used and subcultures were made at intervals to see how long infection persisted. One strain was killed even in the 15,000i.u./ml. solution within 2 days, whereas two strains survived in the 100,000 i.u./ml. solution for 5 days. Recently isolated strains appeared more capable of surviving in the stronger solutions than cultures that had been on artificial media for some time.

TABLE II

PERSISTENCE OF INFECTION IN VARIOUS CONCENTRATIONS OF PENICILLIN

\begin{tabular}{|c|c|c|c|c|c|}
\hline \multicolumn{2}{|c|}{$\begin{array}{c}\text { Strength of Penicillin } \\
\text { Solution (international } \\
\text { units/ml.) ... }\end{array}$} & 100,000 & 50,000 & 25,000 & 15,000 \\
\hline $\begin{array}{l}\text { Time after } \\
\text { Infection } \\
\text { (days) }\end{array}$ & $\begin{array}{l}1 \\
2 \\
3 \\
4 \\
5 \\
6 \\
7\end{array}$ & $\begin{array}{r}27 \\
10 \\
3 \\
2 \\
2 \\
0 \\
0\end{array}$ & $\begin{array}{r}27 \\
23 \\
8 \\
7 \\
3 \\
0 \\
0\end{array}$ & $\begin{array}{r}27 \\
25 \\
11 \\
9 \\
6 \\
0 \\
0\end{array}$ & $\begin{array}{r}27 \\
26 \\
18 \\
14 \\
11 \\
9 \\
8\end{array}$ \\
\hline
\end{tabular}

Control tubes containing water or $\mathbf{0 . 5}$ per cent. sodium citrate were still infected after 3 months.

\section{Summary}

The behaviour of penicillin solutions against Ps. pyocyanea differs according to the strength of the solution.

In weak solutions $P$ s. pyocyanea grows well, and in a solution once contaminated it remains viable for long periods.

In weak solutions the addition of a preservative alone prolongs the life of penicillin. In the stronger solutions the use of a buffer (citrate) is essential, and otherwise the rate of deterioration of the penicillin is very rapid. The use of a preservative is desirable. It was noted that thiomersalate in 0.002 per cent. concentration was compatible with penicillin in spite of the fact that this is a salt of a heavy metal. Other preservatives tried were phenylethyl alcohol, phenylmercuric nitrate, phenylmercuric acetate, and chlorcresol; these appeared to be equally useful.

Stronger penicillin solutions of 15,000 i.u./ml. and upwards are unfriendly 
to Ps. pyocyanea and, depending on the concentration of penicillin and on the viability of the strain, infected solutions containing $100,000,50,000$, an 25,000 -i.u. $/ \mathrm{ml}$. became sterile in 2 to 6 days.

BIGNeLL, J. L. (1951). British Journal of Ophthalmology, 35, 419.

FIELDING, J. (1947). Brit. med. J., 1, 136.

Hobbs, R. J., Livingstone, J. L., Reece, J., and Woodard, W. A. (1952). J. Pharm. Pharmacol 4,911 .

Klein, M., Millwood, E. G., and Walther, W. W. (1954). I Ibid., 6, 725.

LANCET (1944). Lancet, 2, 185.

THEODORE, F. H. (1951). Amer. J. Ophthal., 34, 1764. 